\title{
LIBRI RICEVUTI
}

A. Sona (Editor): Laser and Their Applications. Gordon and Breach, New York, Paris, London, 1976; p. XIV-629; 223.90 .

G. Busch and H. Schade: Lectures on Solid State Physics. Pergamon Press, Oxford, New York, ete., 1976; p. Xv-538; \$35.00.

H. C. Ohanian: Gravitation and Spacetime. W. W. Norton and Company, Inc., New York, 1976; p. xiv-461; s.i.p.

B. K. Tanner: X-Ray Diffraction Topography. Pergamon Press, Oxford, New York, ete., 1976 ; p. XIV-174; $\$ 12.50$.

R. SRinivasan and S. Partinasarathy: Some Statistical Applications in X-Ray Cristallography. Pergamon Press, Oxford, New York, etc., 1976; p. xix-248; \$22.50.

J. Meaburn: Detection and Spectrometry of Faint Light. D. Reidel Publishing Company, Dordrecht, Holland; Boston, Mass., 1976; p. vIII-270; Dfl. 90.00.

R. Berman: Thermal Conduction in Solids. Clarendon Press, Oxford, 1976; p. XI-193; £ 9.75 .

N. H. Marci : Self-Consistent Fields in Atoms. Pergamon Press, Oxford, New York, etc., $1975 ;$ p. IX-233; \$8.25.

G. C. KYKer jr.: Study Guide to Accompany Physics by Paul A. Tipler. Worth Publishers, Inc., 1976; p. X-345; s.i.p.

S. G. Brusir: The Kind of Motion we Call Heat. - Book 1 : Physics and the Atomists. p. XIII-299, Index Xv-XxxIX; Book 2: Statistical Physics and Irreversible Processes. p. xIII-303-769, Index Xv-xxxIx; North-Holland Publishing Company, Amsterdam, New York, Oxford, 1976; \$83.95, 2 volume set.

M. C. Lovell, A. L. Avery and M. W. Vernon: Physical Properties of Materials. Van Nostrand Reinhold Company, New York, Cincinnati, ete., 1976; p. XII-304; £ $12.00 \mathrm{HB}, \mathfrak{f} 5.95 \mathrm{~PB}$.

A. S. DAvYdov: Quantum Mechanics. Translated, Edited and with additions by D. Ter Hanr. Pergamon Press, Oxford, New York, etc., Second Edition, 1976; p. XII-637; \$18.50.

V. G. Soloviev: Theary of Complex Nuclei. Translated by P. Vogel. Pergamon Press, Oxford, New York, ete., 1976; p. X-460;\$35.00.

A. G. Sitenko and V. K. Tartakovskir: Lectures on the Theory of the Nucleus. Translated and Edited by P. J. Shephard. Pergamon Press, Oxford, New York, ete., $1975 ;$ p. XII-304; $\$ 20.00$.

G. G. EichHolz: Environment Aspects of Nuclear Power. Ann Arbor Seience Publishers Inc., Ann. Arbor, Mich., 1976; p. Xx-683; $£ 19.50$.

W.A. Ainswortir: Mechanisms of Speech Recognition. Pergamon Press, Oxford, New York, etc., 1976; p. virI-139; \$10.00.

L. Pal and P. Szepfalusy (Editors): Statistical Physics. Proceedings of the International Conference, August 25-29, 1975, Budapest, Hungary. North-Holland Publishing Company, Amsterdam, Oxford, New York, 1976; p. 251; \$33.95.

J. Rotblat (Editor): Nuclear Reactions. To Breed or Not to Breed. CBE, Taylor and Francis Ltd., London, $1977 ;$ p. 124; $\mathfrak{£} 1.00$. 